\section{The Task of Civics}

As appeal on civics, recently issued by the Parents Association, copies of which are obtainable from Miss Voigt, 37 Vine Lane, Hillingdon, Middlesex (5d., including postage), suggests that two of the most insistent problems confronting parents are how to win physical and political security for our children and for future generations, and how to teach our children to fight more successfully against the innate tendencies towards barbarism which recent history has revealed so clearly in the human mind, and thereby to achieve a civilization far more just, public-spirited and high-minded than ours has recently been. In regard to the first, the circular urges that it is our duty as parents to bring up a hardy race of children, trained and disciplined for defensive war until really reliable machinery has been created for making war impossible in future. In face of the tremendous external dangers which have always existed, though not fully realized, children should not be brought up to the rather soft and easy life which has been usual in western Europe in recent generations, since peace, no less than war, needs strength and discipline.

In regard to moral and spiritual security, many parents have failed to teach their families how to win moral and spiritual stability for themselves. However long the War lasts, and whatever our hardships, we must as parents at home train our young people in future more intelligently and thoroughly in the greater things of life, and inspire them so that they may become strong men and women of action, determined to fight to the uttermost against external enemies as well as against their own selfish nature. The strength, width of sympathy and higher values which we are achieving in this War must be preserved and developed in times of peace. To do this, it is suggested that just as the States of ancient Greece combined together in the fifth century B.c. to defeat the Persian barbarism and went on after victory to found a great civilization, so now we should seek to create with our children's help a new civilization, the greatest yet seen in history. This will involve not merely enduring the present War until the modern barbarian is defeated, but also training our children more carefully than ever so that they may be able to build up such a civilization after the War. It involves also an attempt to re-state the Christian aim so that it may seem to our children more intelligible, more practical and more in keeping with the whole of life. The programme calls for the allegiance of all parties and all classes, a high degree of strength and unselfishness and a determined effort to make our faith more real and to show our children how to find and keep their own faith.

\section{Sir Astley Cooper}

Sir Astley Panton Cooper, the centenary of whose death falls on February 12, was one of the most eminent surgeons and anatomists of the first half of the nineteenth century and a pioneer in experimental and vascular surgery. He was born at Brooke in Norfolk on August 23, 1768. His grandfather was a distinguished surgeon of Norwich and his uncle senior surgeon at Guy's Hospital. He was apprenticed to Henry Clive, surgeon to St. Thomas's Hospital, and after study at Guy's, St. Thomas's, Edinburgh and Paris, succeeded his uncle at Guy's in 1800. Two years later he was awarded the Copley Medal of the Royal Society for two communications on the effect of rupture of the membrana tympani. and was elected F.R.S., becoming a vice-president in 1830. His rise in the medical profession was remarkably rapid. In 1805 he was one of the founders of the Medical and Chirurgical Society, of which he became president in 1819 , he was twice president of the Royal College of Surgeons of England (1827 and 1836), and in 1828 was appointed sergeant-surgeon to George IV and in 1830 to William IV.

The subjects of Sir Astley's principal works were the anatomy and surgical treatment of hernia, of which the first part appeared in 1804 and the second in 1807, dislocations and fractures of the joints (1822), diseases of the breast (1829), structure and diseases of the testis (1830), anatomy of the thymus (1832) and surgical essays in collaboration with Benjamin Travers (1840). His name has been attached to cystic tumour of the breast and to varieties of fasciæ, hernia and ligaments. He received numerous honours from British and foreign universities and learned societies, being member of the Institut de France. D.C.L. of Oxford, Edinburgh and Glasgow, and honorary member of learned societies of Germany. Russia, Italy and Mexico. His portrait by Sir Thomas Lawrence is in the Council Room of the Royal College of Surgeons, and his statue by Baily is in St. Paul's Cathedral; he was buried in the chapel of Guy's Hospital.

\section{Tea-Growing in U.S.S.R.}

$\mathrm{IT}_{\mathrm{T}}$ is reported in Izvestia that the crop of the U.S.S.R. in 1940 produced 23,500 tons of tea. The tea plantations in Georgia, where the bulk of the tea is grown, now occupy an area of 121,000 acres. An additional 7,500 acres will be planted to tea next spring. A certain amount of tea is also grown in Soviet Azerbaijan. Tea-growing was first introduced into Russia fifty-six years ago, at Chakva, near Batum (Georgia). An area of five acres was then planted to tea. The cultivation of tea in Russia made little progress until after the Revolution and the inception of the five-year plans.

\section{Ovarian Follicular Hormones}

Prof. E. A. Doisy informs us that in the preparation of the abstract of a paper of his under this title which was used in Nature of November 9, p. 624, a serious error was made. Prof. Carl Bachman, of the University of Pennsylvania, has made importart contributions to endocrinology, but the synthesis of equilenin was accomplished by Prof. Werner E. Bachmann, of the University of Michigan. Actually Werner E. Bachmann did not synthesize theelin, but Marker had already shown that equilenin can be converted into theelin so, consequently, it was unnecessary for Bachmann to carry his work further than the synthesis of equilenin. 